\title{
Cell Culture, Oxidative Stress, and Antioxidants: Avoiding Pitfalls
}

\author{
Barry Halliwell
}

\begin{abstract}
Cell culture is widely used by biochemists and cell/molecular biologists, but the fluctuating (and often elevated) levels of $\mathrm{O}_{2}$ to which cells in culture are exposed can affect many of their properties. So can the low level of antioxidants found in some cell culture media. Reagents, especially "antioxidants," added to cell culture media can react with the constituents of the media to produce $\mathrm{H}_{2} \mathrm{O}_{2}$ and degradation products that can influence cell behavior. Several published papers describing the cellular effects of ascorbate, polyphenols, and carotenoids have, in fact, reported artifacts due to the actions of the degradation products of these "antioxidants." A greater awareness of the potential artifacts in cell culture studies is needed among the free radical/antioxidant community. (Biomed J 2014;37:99-105)
\end{abstract}

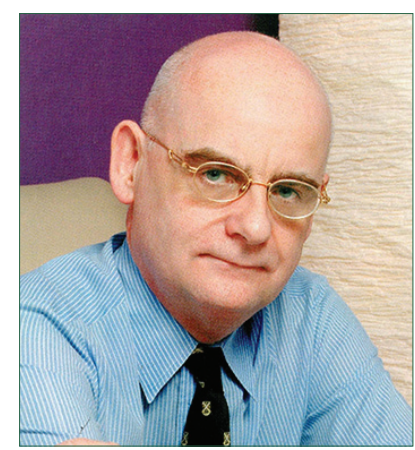

Prof. Barry Halliwell

\section{Key words: antioxidant, ascorbate, cell culture, flavonoid, oxidative stress, oxygen radicals}

$\mathrm{T}$ This review is an update and expansion of my article ${ }^{[1]}$ in 2003, entitled "Oxidative stress in cell culture: An under-appreciated problem." Over 10 years later, the problems are still under-appreciated and artifactual results are still being published, hence the need for another commentary on the topic.

Cell culture is used by researchers worldwide to elucidate metabolic pathways and to discover the mechanisms involved in cell signaling, regulation of gene expression and protein synthesis, cell proliferation, senescence, and cell death. Cell culture studies have provided a huge amount of valuable information, including helping to elucidate important physiological roles of mitogen-activated protein (MAP) kinases, nuclear factor kappa-light-chain-enhancer of activated $B$ cells (NFKB), activator protein-1 (AP-1), nuclear transcription factor erythroid 2p45-related factor-2 (Nrf2), nitric oxide, and caspases, among many other agents. There is also growing interest in using reprogrammed stem cells from patients to study the mechanisms of disease, e.g. in amyotrophic lateral sclerosis. ${ }^{[2]}$

However, it must be realized that cells in culture are different from those in vivo in many ways. The normal cell matrix (which has important influences on cell morphology and function) is absent, as are other cell types that normally surround the cells in question and communicate with them. For example, isolated neurons are very vulnerable to dam- age, but in vivo glia help to regulate their metabolism and protect them against damage. ${ }^{[3]} \mathrm{A}$ huge range of agents, from cytotoxic drugs to dietary antioxidants, show remarkable effects when added to cells in culture, yet many are a disappointment when tried in vivo. ${ }^{[1]}$ Rapid metabolism and limited bioavailability of agents tested in vivo are obvious explanations for this discrepancy. However, cell culture imposes an oxidative stress that may, under certain circumstances, lead to misleading conclusions. ${ }^{[1]}$ Another important factor is misidentification of cell lines (the cell is not what it is supposed to be) ${ }^{[4-9]}$ Even when the cell line is correct, it may have a genotype (e.g. apoE) not reflective of the in vivo status. ${ }^{[10]}$ Genetic drift is frequent; mutations occur rapidly in cell culture, ${ }^{[11]}$ as exemplified by studies on HeLa cells. ${ }^{[12]}$ Indeed, many cell culture studies are carried out using malignant cell lines such as HeLa because such cells are robust and grow and divide easily in culture. This makes sense when looking for chemotherapeutic agents, but perhaps less sense when trying to elucidate normal metabolic or signaling pathways.

An alternative is primary culture, where cells are harvested from a tissue and plated. Some of them will survive, but many die because of the stress of the isolation procedure and the "foreign environment" of the culture conditions. This is also true of many cancer cells; they often need support from the surrounding stroma in vivo

From the Department of Biochemistry, National University of Singapore, Singapore

Received: Feb. 13, 2014; Accepted: Feb. 17, 2014

Correspondence to: Prof. Barry Halliwell, Department of Biochemistry, National University of Singapore, Singapore. 21 Lower Kent Ridge Road, Singapore - 119 077. Tel: 65-65163247; Fax: 65-67752207; E-mail: bchbh@ @us.edu.sg

DOI: $10.4103 / 2319-4170.128725$ 
to survive and only those that can adapt to the loss of this, and to other aspects of cell culture conditions, will proliferate. ${ }^{[13]}$ Values of $1-10 \%$ have been quoted for the number of originally harvested cells from a tissue that survive. ${ }^{[14]}$ The words "culture shock" have been used to describe this phenomenon ${ }^{[1,14]}$ To take examples, isolation of rat hepatocytes can lead to activation of nitric oxide synthase within them, generating levels of nitric oxide (NO) sufficient to alter cell metabolism. ${ }^{[15]}$ Treatment of cells with trypsin can cause a decrease in the cellular levels of reduced glutathione (GSH). ${ }^{[16,17]}$ The cells which survive the culture shock appear to be those that have adapted rapidly, with multiple changes in gene expression, metabolic activity, and the levels of many enzymes. ${ }^{[13,17-19]}$ Some enzyme levels are increased, other swiftly decreased. ${ }^{[19]}$ Thus, only a fraction, and probably an unrepresentative fraction, of the initially plated cells survives. As an example, p53 is not expressed in 14-day mouse embryos, but in culture of fibroblasts from them, the cells that survived were those that had begun to express it. ${ }^{[20]}$ Indeed, cell cultures often show abnormal p53 activity. ${ }^{[21]}$ Cells may change their properties, e.g. glial cells can be activated during the processing of brain tissue, which is required for their isolation. ${ }^{[22]}$

\section{The oxidative stress of cell culture}

Culture shock affects cells in multiple ways, one key action being to impose oxidative stress. The term "oxidative stress" refers to a serious imbalance between the levels of reactive oxygen species (ROS) in a cell and its antioxidant defenses in favor of the ROS. ${ }^{[23,24]}$ Cell culture causes oxidative stress for two reasons: (A) It leads to more ROS generation and (B) it can impair cellular antioxidant defenses. Let us examine how these events happen.

\section{More ROS generation}

Most cells in vivo in animals are exposed to low $\mathrm{O}_{2}$ concentrations, in the range of $1-10 \mathrm{~mm} \mathrm{Hg}$, although there are obvious exceptions (including skin epidermis, cornea of the eye, and the cells lining the respiratory tract).$^{[1,25-27]}$ Cell culture is commonly performed under $95 \%$ air $/ 5 \% \mathrm{CO}_{2}$, an $\mathrm{O}_{2}$ tension of approximately $150 \mathrm{~mm} \mathrm{Hg}$. Since the rates of production of ROS [superoxide $\left(\mathrm{O}_{2}^{\cdot-}\right)$ and hydrogen peroxide $\left(\mathrm{H}_{2} \mathrm{O}_{2}\right)$ ] by cellular enzyme systems and by "leakage" of electrons from electron transport chains are limited at normal cellular levels, elevated $\mathrm{O}_{2}$ will thus increase ROS production. ${ }^{[1,25-27]}$ Therefore, more ROS will be produced in cells in culture. Depending on the magnitude and time course, increased ROS production might cause increased cell proliferation, halt proliferation, or lead to senescence, cell death, or adaptation. ${ }^{[24,28]}$ Even in the cells that adapt and proliferate, their properties are likely to be altered (e.g. changes in mitochondrial morphology and function) ${ }^{[29]}$ One important example of this was revealed by attempts to determine the "Hayflick limit," the number of times that cells can divide in culture before they undergo senescence. ${ }^{[14]}$ For human fibroblasts, a value of 40-50 doublings was originally suggested. A study by Shay et $a l^{[14]}$ revealed that if cells are grown at low $\mathrm{O}_{2}$, many more doublings are possible. The original Hayflick limits were artifactually low, due in part to culture-related oxidative stress causing accelerated telomere shortening. ${ }^{[14,30,31]}$ Cells whose properties are very different when grown under physiological $\mathrm{O}_{2}$ levels as opposed to $21 \% \mathrm{O}_{2}$ include chondrocytes, ${ }^{[32]}$ hepatocytes, ${ }^{[33]}$ and several malignant cell types, especially as many tumor cells experience hypoxia in vivo. ${ }^{[13,34,35]}$ Another problem is that the $\mathrm{O}_{2}$ levels in cell culture can fluctuate wildly, being high when the cells are first placed in air-saturated culture medium and dropping as the cells grow, proliferate, and consume $\mathrm{O}_{2}$. Often an $\mathrm{O}_{2}$ gradient is established between the surface of the medium and the cells beneath. When the medium is changed, cells can therefore switch from relative hypoxia to hyperoxia and suffer the equivalent of a hypoxia-reperfusion injury. ${ }^{[24]}$ The density of the cells under study is also important to consider; the denser they are, the faster the $\mathrm{O}_{2}$ will be consumed, and products such as $\mathrm{H}_{2} \mathrm{O}_{2}$ can more readily diffuse into adjacent cells for metabolism.

How can cells adapt to the oxidative stress of cell culture? This might involve, in principle, increased levels of antioxidant defenses, down-regulating the production of ROS, such as decreasing the levels of or adapting mitochondrial or endoplasmic reticulum electron transport chains to produce less $\mathrm{O}_{2}^{--}$. An additional strategy is to change cellular targets of oxidative damage so that they become more resistant to damage by ROS. ${ }^{[24,25,36-38]}$ All these adaptations can be facilitated by an ROS-dependent increased frequency of mutations. Further evolution might then take place; a cell that has adapted to cope with the oxidative stress of cell culture might further evolve to use ROS. For example, some malignant cells in culture appear to have "learned" to use ROS to promote proliferation and suppress apoptosis. ${ }^{[39,40]}$ Non-malignant cells may evolve similarly; because more ROS are produced under the pro-oxidant environment of cell culture, cells might adapt to utilize ROS-dependent signal transduction pathways that rarely, if ever, operate in vivo in healthy tissues. ${ }^{[11,42]}$ It is not impossible that some of the widely investigated ROS-dependent signaling pathways used by cells in culture to respond to cytokines, growth factors, and other stimuli are not physiological. ${ }^{[24,41,42]}$

The culture process also alters cell metabolism. For example, Chinese Hamster Ovary (CHO) cells in culture metabolize abnormally large amounts of glucose via the pentose phosphate pathway. They also increase oxaloacetate production, both events seemingly as an adaptation to the oxidative stress of cell culture. ${ }^{[43]}$ Indeed, cellular production of pyruvate was suggested many years ago as a similar adaptation, ${ }^{[44]}$ since pyruvate, oxaloacetate, and $\alpha$-ketoglutarate can scavenge $\mathrm{H}_{2} \mathrm{O}_{2}$ readily in cell culture media. ${ }^{[44-49]}$ 


\section{Hyperglycemia}

In the human body, cells are normally exposed to a glucose level of around 4-5 mM, although of course this may rise shortly after a meal and then fall again. By contrast, the concentrations of glucose in various cell culture media are highly variable. Several media use $5.5 \mathrm{mM}$ levels, which are approximately physiological. Yet others have levels of 11 to as high as $55 \mathrm{mM}$. High glucose for prolonged periods increases mitochondrial $\mathrm{O}_{2}^{--}$generation in cells, leading to severe perturbation of metabolism and alterations of cell function. ${ }^{[50,51]}$ High glucose also causes glycation and glycoxidation of proteins, with the potential to impair cell metabolism (analogous to the sequelae of diabetes in humans).

\section{Fewer antioxidants}

Cell culture media are frequently deficient in the antioxidants that are normally obtained in the human diet and delivered to cells by the bloodstream. This is especially true of tocopherols and ascorbate. Vitamin E is rarely added to cell culture media because it is insoluble in water (some amount will be provided in calf serum, although the exact levels are seldom measured) and vitamin $\mathrm{C}$ is not added because it is unstable. Hence, cells in culture can be deficient in important antioxidants, a situation which can lead to overinterpretation of the actions of added antioxidants..$^{[1,24,52,53]}$ Antioxidants often appear to have beneficial effects when added to cultured cells, but this can be because a severe deficiency is being corrected, rather than being a real beneficial effect of "extra antioxidants." Culture media can be deficient in selenium; ${ }^{[52,54,55]}$ this deficiency may decrease (or at least prevent oxidative stresstriggered increases in) the activities of selenium-dependent antioxidant systems. These include thioredoxin reductase, certain methionine sulfoxide reductases, and most members of the glutathione peroxidase enzyme family. ${ }^{[24,52]}$ If thioredoxin reductase activity is decreased, cell metabolism and antioxidant defenses will be seriously impaired, particularly of the peroxiredoxins, the major scavengers of $\mathrm{H}_{2} \mathrm{O}_{2}$ in most cell types. ${ }^{[24,56]}$

\section{Cell culture media can be pro-oxidant ${ }^{[1,24]}$}

Cells require transition metal ions, especially iron and copper, in order to grow. Indeed, all laboratory solutions and cell culture media are contaminated with such ions. ${ }^{[24,57,58]}$ In some cell culture media, inorganic metal ions are also added deliberately. Indeed, the widely used Dulbecco's modified Eagle's medium (DMEM) contains added iron(III) nitrate, $\mathrm{Fe}\left(\mathrm{NO}_{3}\right)_{3}$. "Free" iron is also present in Ham's FIO medium, often used to study the oxidation of low density lipoprotein (LDL) in vitro. ${ }^{[58]}$ In other media, iron is mostly supplied in transferrin-bound form, usually in the widely used calf serum. Whereas transferrin-bound iron will not normally catalyze free radical reactions, ${ }^{[24,59]}$ contaminat- ing (or added) "free" iron ions can be pro-oxidant, as can be copper and many other transition metal ions. ${ }^{[24]}$

Ascorbate, flavonoids, many other polyphenolic compounds, and thiols are unstable in the commonly used cell culture media, undergoing rapid oxidation to generate $\mathrm{H}_{2} \mathrm{O}_{2}$ and often other ROS such as superoxide. ${ }^{[1,45-47,60-67]}$ Studies in my laboratory have revealed that many of the apparent effects of these molecules on cells in culture are artifacts due to their oxidation in the cell culture medium. Examples to illustrate this are accumulating in the literature; Table 1 summarizes some of them. Indeed, the problem may be more widespread. Many substances, including agents used as allegedly specific inhibitors of signal transduction systems and metabolic pathways, are polyphenolic compounds, and thus likely to be highly oxidizable in cell culture media and prone to generate artifacts if added at high concentrations [Table 1]. Yet another mechanism of pro-oxidant effects is photochemical. If light intensity is sufficiently high, riboflavin in culture media can cause photochemical ROS formation. ${ }^{[68,69]}$

The extent of the artifacts depends on several factors, including the batch of cell culture medium, the cell density, and the medium content of keto acids such as pyruvate. Of course, if the keto acids present scavenge $\mathrm{H}_{2} \mathrm{O}_{2}$, they will then be depleted, causing further changes in cell metabolism. Leakage of catalase from cells in culture can increase the medium levels of this enzyme in some cases, and a human T-cell line was able to grow in culture at high, but not low cell densities for this reason. ${ }^{[70]} \mathrm{A}$ "protective factor" isolated from medium previously used to grow hepatocytes was able to protect other cells against the cytotoxicity of gallic acid; the factor was identified as catalase. ${ }^{[71]}$ This is not surprising because the toxicity of gallic acid is due to its oxidation to produce $\mathrm{H}_{2} \mathrm{O}_{2}$ in the cell culture medium. ${ }^{[72]}$ Extracellular superoxide dismutase may also be secreted into the surrounding medium by some cell types and can slow down the autoxidation rate of polyphenols, which often involves $\mathrm{O}_{2}^{--} \cdot{ }^{[73,74]}$ Catalase in the medium can protect against $\mathrm{H}_{2} \mathrm{O}_{2}$ generated both intracellularly and extracellularly, since $\mathrm{H}_{2} \mathrm{O}_{2}$ readily crosses the cell membranes and so external catalase can "drain" $\mathrm{H}_{2} \mathrm{O}_{2}$ out of the cell. ${ }^{[24]}$

Sometimes compounds oxidize in cell culture media but do not generate $\mathrm{H}_{2} \mathrm{O}_{2}$. Compounds that break down rapidly in cell culture media without substantial $\mathrm{H}_{2} \mathrm{O}_{2}$ generation include lycopene and some other carotenoids, resveratrol, and curcumin; the reported effects of these compounds on cells in culture may be due to their oxidation products. ${ }^{[75,76}$ Thus, if a compound does not generate $\mathrm{H}_{2} \mathrm{O}_{2}$ in a cell culture medium, or if its cellular effects are not prevented by adding catalase, do not assume that it is stable in that medium. ${ }^{[75}$ The toxicity of dopamine to cells in culture was found to be due to its rapid oxidation to form not only $\mathrm{H}_{2} \mathrm{O}_{2}$ but also 
Table 1: Examples of artifacts caused by oxidation of compounds added to cell culture media*

\begin{tabular}{|c|c|}
\hline Observation & Comment \\
\hline $\begin{array}{l}\text { Induction of cell death by ascorbate in HL-60 or acute myeloid } \\
\text { leukemia cells or human fibroblasts }\end{array}$ & $\begin{array}{l}\text { Due to generation of } \mathrm{H}_{2} \mathrm{O}_{2} \text { by ascorbate oxidation in cell culture media. Other } \\
\text { reported effects of ascorbate on cells in culture (e.g. promoting differentiation } \\
\text { of stem cells) might also be due to } \mathrm{H}_{2} \mathrm{O}_{2} \text { generation }\end{array}$ \\
\hline $\begin{array}{l}\text { Ascorbate observed to inhibit cell proliferation and fibronectin } \\
\text { synthesis in human skin fibroblasts }\end{array}$ & $\begin{array}{l}\text { Inhibition by catalase suggests that the observed effect is due to } \mathrm{H}_{2} \mathrm{O}_{2} \\
\text { generation in the culture medium }\end{array}$ \\
\hline Induction of apoptosis by green tea in PC12 cells & Due to generation of $\mathrm{H}_{2} \mathrm{O}_{2}$ by oxidation of tea components in cell culture media \\
\hline $\begin{array}{l}\text { Induction of cell death by 1-DOPA and dopamine in PC12 and } \\
\text { M14 cells }\end{array}$ & $\begin{array}{l}\text { Due to } \mathrm{H}_{2} \mathrm{O}_{2} \text {, quinones, and semiquinones generated by the oxidation of } \\
\text { 1-DOPA and dopamine in the culture medium }\end{array}$ \\
\hline Toxicity of apple phenolics to cancer cells & Due to oxidation to produce $\mathrm{H}_{2} \mathrm{O}_{2}$ in the culture medium \\
\hline Cytotoxicity of gallic acid & $\begin{array}{l}\text { Largely or entirely due to oxidation of gallic acid to produce } \mathrm{H}_{2} \mathrm{O}_{2} \text { in the } \\
\text { culture medium }\end{array}$ \\
\hline
\end{tabular}

Addition of grape seed extract to Caco-2 cell culture medium generates $\mathrm{H}_{2} \mathrm{O}_{2}$ due to oxidation of phenolics in the medium Effects of polyphenols on c-jun phosphorylation in bronchial epithelial cell lines

Epigallocatechin gallate induces apoptosis in human oral cell lines Toxicity of myricetin to Chinese hamster lung fibroblast V79 cells

Cell culture media found to generate ROS as detected by spin traps and fluorescent dyes

Stimulation of SIRT1 activity by polyphenols in HT29 cells Cyanidin-3-rutoside toxic to HL60 cells

EGCG and green tea extract cause oxidative stress responses in Saccharomyces cerevisiae

Cytotoxicity of EGCG to oral carcinoma cell lines

Activation of NF- $\kappa \mathrm{B}$ in macrophages by coffee

Toxicity of catechols to PC12-AC cells

Toxicity of EGCG to Jurkat T cells

Cytotoxicity and genotoxicity of green tea extract to $\mathrm{H} 260$ and RAW264.7 cells

$-$

Shown to involve $\mathrm{H}_{2} \mathrm{O}_{2}$, although $\mathrm{H}_{2} \mathrm{O}_{2}$ was not specifically identified as coming from the culture medium

Due to production of $\mathrm{H}_{2} \mathrm{O}_{2}$ in the culture medium

Due to $\mathrm{H}_{2} \mathrm{O}_{2}$ production, although $\mathrm{H}_{2} \mathrm{O}_{2}$ was not specifically identified as coming from the culture medium

$\operatorname{Ref}^{[82]}$

Results confounded by instability of polyphenols in the culture medium Shown to involve peroxide, although $\mathrm{H}_{2} \mathrm{O}_{2}$ was not specifically identified as coming from the culture medium

Involves $\mathrm{H}_{2} \mathrm{O}_{2}$ production in the medium

Involves both $\mathrm{H}_{2} \mathrm{O}_{2}$ and quinones, although these did not account for all the effects

Due to $\mathrm{H}_{2} \mathrm{O}_{2}$; coffee contains substantial $\mathrm{H}_{2} \mathrm{O}_{2}$ levels ${ }^{[83]}$

Involves $\mathrm{H}_{2} \mathrm{O}_{2}$, mainly generated in the extracellular medium

Involves $\mathrm{H}_{2} \mathrm{O}_{2}$ generation in the culture medium

Involves $\mathrm{H}_{2} \mathrm{O}_{2}$ generation, although $\mathrm{H}_{2} \mathrm{O}_{2}$ was not specifically identified as coming from the culture medium

Toxicity of extracts of the oriental fungus Ganoderma lucidum to Involves $\mathrm{H}_{2} \mathrm{O}_{2}$ generation ${ }^{[80]}$ human lymphocytes

Toxicity of quercetin, catechin, and ascorbate to pancreatic $\beta$-cells Toxicity of 4-methylcatechol to murine tumor cells

Toxicity of EGCG to ovarian cancer calls in DMEM

Stimulatory effects of garcinol on growth of intestinal cells

Involves $\mathrm{H}_{2} \mathrm{O}_{2}$ generation in the cell culture medium

Involves oxidation to form $\mathrm{H}_{2} \mathrm{O}_{2}$ and quinones/semiquinones in the cell culture medium

Due to $\mathrm{H}_{2} \mathrm{O}_{2}$ formation, probably both intracellularly and in the culture medium Involves ROS production in the culture medium; ${ }^{[81]}$ low levels of $\mathrm{H}_{2} \mathrm{O}_{2}$ often stimulate cell proliferation ${ }^{[1,24]}$

*Updated from Arch. Biochem. Biophys. 476, 107, 2008 with permission from Elsevier

cytotoxic quinones/semiquinones that could be scavenged by adding GSH to the culture medium. ${ }^{[77]}$ Sometimes they can lead to adaptations by activating the Nrf2 system. ${ }^{[67,78]}$

\section{Conclusion}

Cells that survive and grow in culture are often not representative of cells in vivo, in terms of metabolism, gene expression, and enzyme levels, and there is a need for caution in extrapolating data obtained in cell culture to the in vivo situation. This is widely recognized by researchers, although not always fully considered. Less widely recognized is the extent of the oxidative stress that can be caused by the cell culture process. Thus, ROS-dependent signal transduction pathways identified in cultured cells need to be validated in knockout or transgenic animals. ${ }^{[24,41,42]}$ Similarly, in studies of cellular effects of autoxidizable biomolecules or plant extracts containing them [Table 1], it must be realized that ROS production can occur by chemical reactions in the culture media. ${ }^{[79,80]}$ The stability of such compounds in the culture medium, and their propensity to produce ROS and other oxidation products, must be checked before beginning cell studies. Depending on the cell type and the amount of 
ROS produced, these species might exert toxic effects. This explains many of the previously reported cellular effects of thiols, ascorbate, and phenols [Table 1]. The resistance of cells to damage by ROS varies widely, depending on the extent to which the cell has adapted to the oxidative stress of the cell culture milieu. Low levels of $\mathrm{H}_{2} \mathrm{O}_{2}$ can have the paradoxical effect of accelerating proliferation in some cell types. ${ }^{[24,28,81]}$

\section{Acknowledgments}

I thank the National Medical Research Council, the Biomedical Research Council, the Ministry of Education, the Tan Chin Tuan Foundation, and the Academic Research Fund of the National University of Singapore for grant support. I am grateful to Dr. Sebastian Schaffer and Ms. Lee Hua Long for advice on the glucose content in cell culture media.

\section{REFERENCES}

1. Halliwell B. Oxidative stress in cell culture: An under-appreciated problem. FEBS Lett 2003;540:3-6.

2. Vogel G. Stem Cells. Diseases in a dish take off. Science 2010;330:1172-3.

3. Schwartz M, Kipnis J, Rivest S, Prat A. How do immune cells support and shape the brain in health, disease, and aging? J Neurosci 2013;33:17587-96.

4. Nardone RM. Curbing rampant cross-contamination and misidentification of cell lines. Biotechniques 2008;45:221-7.

5. American Type Culture Collection Standards Development Organization Workgroup ASN-0002. Cell line misidentification: The beginning of the end. Nat Rev Cancer 2010;10:441-8.

6. Capes-Davis A, Theodosopoulos G, Atkin I, Drexler HG, Kohara A, MacLeod RA, et al. Check your cultures! A list of cross-contaminated or misidentified cell lines. Int J Cancer 2010;127:1-8.

7. Vogel G. Cell biology. To scientists' dismay. Mixed-up cell lines strike again. Science 2010;329:1004.

8. Lee LE, Bufalino MR, Christie AE, Frischer ME, Soin T, Tsui CK, et al. Misidentification of OLGA-PH-J/92, believed to be the only crustacean cell line. In Vitro Cell Dev Biol 2011;47:665-74.

9. Wu ML, Liao LC, Chen CY, Lee SY, Yuan GF, Hwang SM. A 2-yr service report of cell line authentication. In Vitro Cell Dev Biol Anim 2013;49:743-5.

10. Schaffer S, Lam YM, Ernst IM, Huebbe P, Rimbach G, Halliwell B. Variability in APOE genotype status in human-derived cell lines: A cause for concern in cell culture studies? Genes Nutr 2014;9:364.

11. Wang CY, Liu LN, Zhao ZB. The role of ROS toxicity in spontaneous aneuploidy in cultured cells. Tissue Cell 2013;45:47-53.

12. Heng HH. HeLa genome versus donor's genome. Nature 2013;501:167.

13. Weinberg RA. The Biology of Cancer, $2^{\text {nd }}$ ed. New York and London: Garland Press; 2014. p. 585-7.

14. Wright WE, Shay JY. Historical claims and current interpretations of replicative ageing. Nat Biotechnol 2002;20:682-8.
15. López-García MP, Sanz-González SM. Peroxynitrite generated from constitutive nitric oxide synthase mediates the early biochemical injury in short-term cultured hepatocytes. FEBS Lett 2000;466:187-91.

16. Reiners JJ Jr, Mathieu P, Okafor C, Putt DA, Lash LH. Depletion of cellular glutathione by conditions used for the passaging of adherent cultured cells. Toxicol Lett 2000;115:153-63.

17. Bishop CT, Mirza Z, Crapo JD, Freeman BA. Free radical damage to cultured porcine aortic endothelial cells and lung fibroblasts: Modulation by culture conditions. In Vitro Cell Dev Biol Anim 1985;21:229-36.

18. Tu B, Wallin A, Moldéus P, Cotgreave IA. Individual, culture-specific alterations in the human endothelial glutathione system: Relationships to oxidant toxicity. Pharmacol Toxicol 1994;75:82-90.

19. Baker TK, Carfagna MA, Gao H, Dow ER, Li Q, Searfoss GH, et al. Temporal gene expression of monolayer cultured rat hepatocytes. Chem Res Toxicol 2001;14:1218-31.

20. Mendrysa SM, Perry ME. The p53 tumor suppressor protein does not regulate expression of its own inhibitor, MDM2, except under conditions of stress. Mol Cell Biol 2000;20:2023-30.

21. Millau JF, Mai S, Bastien N, Douin R. p53 functions and cell lines: Have we learned the lessons from the past? Bioessays 2010;32:392-400.

22. Streit WJ. Microglial activation and neuroinflammation in Alzheimer's disease: A critical examination of recent history. Front Aging Neurosci 2010;2:22.

23. Sies H: Oxidative Stress II, Oxidants and Antioxidants. New York: Academic Press; 1999.

24. Halliwell B, Gutteridge JM. Free Radicals in Biology and Medicine, $5^{\text {th }}$ ed. Oxford: Oxford University Press; 2015 [In Press].

25. de Groot H, Littauer A. Hypoxia, reactive oxygen and cell injury. Free Radic Biol Med 1989;6:541-51.

26. Yusa T, Crapo JD, Freeman BA. Hyperoxia enhances lung and liver nuclear superoxide generation. Biochim Biophys Acta 1984;798:167-74.

27. Turrens JF, Freeman BA, Levitt JG, Crapo JD. The effect of hyperoxia on superoxide production by lung submitochondrial particles. Arch Biochem Biophys 1982;217:401-10.

28. Davies KJ. The broad spectrum of responses to oxidants in proliferating cells: A new paradigm for oxidative stress. IUBMB Life 1999;48:41-7.

29. Fan $\mathrm{X}$, Hussien R, Brooks GA. $\mathrm{H}_{2} \mathrm{O}_{2}$-induced mitochondrial fragmentation in $\mathrm{C} 2 \mathrm{C} 12$ myoctes. Free Radic Biol Med 2010;49:1646-54.

30. Ramirez RD, Morales CP, Herbert BS, Rohde JM, Passons C, Shay JW, et al. Putative telomere-independent mechanisms of replicative aging reflect inadequate growth conditions. Genes Dev 2001;15:398-403.

31. von Zglinicki T. Oxidative stress shortens telomeres. Trends Biochem Sci 2002;27:339-44.

32. Oze H, Hirao M, Ebina K, Shi K, Kawato Y, Kaneshiro S, et al. Impact of medium volume and oxygen concentration in the incubator on pericellular oxygen concentration and differentiation of murine chondrogenic cell culture. In Vitro Cell Dev Biol Anim 2012;48:123-30.

33. Lillegard JB, Fisher JE, Nedredal G, Luebke-Wheeler J, Bao J, Wang W, et al. Normal atmospheric oxygen tension and the use of 
antioxidants improve hepatocyte spheroid viability and function. J Cell Physiol 2011;22:2987-96.

34. Carrera S, de Verdier PJ, Khan Z, Zhao B, Mahale A, Bowman KJ, et al. Protection of cells in physiological oxygen tensions against DNA damage-induced apoptosis. J Biol Chem 2010;285:13658-65.

35. Olin MR, Andersen BM, Litterman AJ, Grogan PT, Sarver AL, Robertson PT, et al. Oxygen is a master regulator of the immunogenicity of primary human glioma cells. Cancer Res 2011;71:6583-9.

36. Zhao HW, Ali SS, Haddad GG. Does hyperoxia selection cause adaptive alterations of mitochondrial electron transfer chain activity leading to a reduction of superoxide production? Antioxid Redox Signal 2012;16:1071-6.

37. Barja G, Cadenas S, Rojas C, Pérez-Campo R, López-Torres M. Low mitochondrial free radical production per unit $\mathrm{O}_{2}$ consumption can explain the simultaneous presence of high longevity and high aerobic metabolic rate in birds. Free Radic Res 1994;21:317-27.

38. Gille JJ, Joenje H. Chromosomal instability and progressive loss of chromosomes in HeLa cells during adaptation to hyperoxic growth conditions. Mutat Res 1989;219:225-30.

39. Pervaiz S, Clement MV. Superoxide anion: Oncogenic reactive oxygen species. Int J Biochem Cell Biol 2007;39:1297-304.

40. Liu R, Li B, Qiu M. Elevated superoxide production by active H-ras enhances human lung WI-38VA-13 cell proliferation, migration and resistance to TNF-alpha. Oncogene 2001;20:1486-96.

41. Halliwell B. Free radicals, proteins and DNA: Oxidative damage versus redox regulation. Biochem Soc Trans 1996;24:1023-7.

42. Halliwell B. Biochemistry of oxidative stress. Biochem Soc Trans 2007;35:1147-9.

43. Ahn WS, Antoniewicz MR. Metabolic flux analysis of CHO cells at growth and non-growth phases using isotopic tracers and mass spectrometry. Metab Eng 2011;13:598-609.

44. O’Donnell-Termey J, Nathan CF, Lanks K, DeBoer CJ, de la Harpe J. Secretion of pyruvate. An antioxidant defense of mammalian cells. J Exp Med 1987;165:500-14.

45. Long LH, Halliwell B. The effects of oxaloacetate on hydrogen peroxide generation from ascorbate and epigallocatechin gallate in cell culture media: Potential for altering cell metabolism. Biochem Biophys Res Commun 2012;471:446-50.

46. Long LH, Halliwell B. Artefacts in cell culture: Pyruvate as a scavenger of hydrogen peroxide generated by ascorbate or epigallocatechin gallate in cell culture media. Biochem Biophys Res Commun 2009;388:700-4.

47. Long LH, Halliwell B. Artefacts in cell culture: $\alpha$-ketoglutarate can scavenge hydrogen peroxide generated by ascorbate and epigallocatechin gallate in cell culture media. Biochem Biophys Res Commun 2011;406:20-4

48. Miwa H, Fujii J, Kanno H, Taniguchi N, Aozasa K. Pyruvate secreted by human lymphoid cell lines protects cells from hydrogen peroxide mediated cell death. Free Radic Res 2000;33:45-56.

49. Babich H, Liebling EG, Burger RF, Zuckerbraun HL, Schuck AG. Choice of DMEM, formulated with or without pyruvate, plays an important role in assessing the in vitro cytotoxicity of oxidants and prooxidant nutraceuticals. In Vitro Cell Dev Biol Anim 2009;45:226-33.
50. Giacco F, Brownlee M. Oxidative stress and diabetic complications. Circ Res 2010;107:1058-70.

51. Crespo FL, Sobrado VR, Gomez L, Cervera AM, McCreath KJ. Mitochondrial reactive oxygen species mediate cardiomyocyte formation from embryonic stem cells in high glucose. Stem Cells 2010;28:1132-42.

52. Leist M, Raab B, Maurer S, Rösick U, Brigelius-Flohé. Conventional cell culture media do not adequately supply cells with antioxidants and thus facilitate peroxide-induced genotoxicity. Free Radic Biol Med 1996;21:297-306.

53. Smith AR, Visioli F, Hagen TM. Vitamin C matters: Increased oxidative stress in culture human aortic endothelial cells without supplemental ascorbic acid. FASEB J 2002;16:1102-4.

54. Baker RD Jr, Baker SS, Rao R. Selenium deficiency in tissue culture: Implications for oxidative metabolism. J Pediatr Gastroenterol Nutr 1998;27:387-92.

55. Karlenius TC, Shah F, Yu WC, Hawkes HK, Tinggi U, Clarke FM, et al. The selenium content of cell culture serum influences redox-regulated gene expression. Biotechniques 2011;50:295-301.

56. Rhee SG, Woo HA, Kil IS, Bae SH. Peroxiredoxin functions as a peroxidase and a regulator and sensor of local peroxide. $\mathrm{J}$ Biol Chem 2012;287:4403-10

57. Evans PJ, Tredger JM, Dunne JB, Halliwell B. Catalytic metal ions and the loss of reduced glutathione from University of Wisconsin preservation solution. Transplantation 1996;62:1046-9.

58. Firth CA, Gieseg SP. Redistribution of metal ions to control low density lipoprotein oxidation in Ham's F10 medium. Free Radic Res 2007;41:1109-15.

59. Aruoma OI, Halliwell B. Superoxide-dependent and ascorbate-dependent formation of hydroxyl radicals from hydrogen peroxide in the presence of iron. Are lactoferrin and transferrin promoters of hydroxyl-radical generation? Biochem J $1987 ; 241: 273-8$

60. Long LH, Clement MV, Halliwell B. Artifacts in cell culture: Rapid generation of hydrogen peroxide on addition of (-) - epigallocatechin, $(-)$ - epigallocatechin gallate, $(+)$ - catechin and quercetin to commonly used cell culture media. Biochem Biophys Res Commun 2000;273:50-3.

61. Hua Long L, Halliwell B. Oxidation and generation of hydrogen peroxide by thiol compounds in commonly used cell culture media. Biochem Biophys Res Commun 2000;286:991-4.

62. Clement MV, Ramalingam J, Long LH, Halliwell B. The in vitro cytotoxicity of ascorbate depends on the culture medium used to perform the assay and involves hydrogen peroxide. Antioxid Redox Signal 2001;3:157-63.

63. Halliwell B. Are polyphenols antioxidants or pro-oxidants? What do we learn from cell culture and in vivo studies? Arch Biochem Biophys 2008;476:107-12.

64. Long LH, Kirkland D, Whitwell J, Halliwell B. Different cytotoxic and clastogenic effects of epigallocatechin gallate in various cell-culture media due to variable rates of its oxidation in the culture medium. Mutat Res 2007;634:177-83.

65. Roques SC, Landrault N, Teissèdre PL, Laurent C, Besançon P, Rouane JM, et al. Hydrogen peroxide generation in caco- 2 cell culture medium by addition of phenolic compounds: Effect of ascorbic acid. Free Radic Res 2002;36:593-9. 
66. Kern M, Fridrich D, Reichert J, Skrbek S, Nussher A, Hofem S, et al. Limited stability in cell culture medium and hydrogen peroxide formation affect the growth inhibitory properties of delphinidin and its degradation product gallic acid. Mol Nutr Food Res 2007;51:1163-72.

67. Erlank H, Elmann A, Kohen R, Kanner J. Polyphenols activate Nrf2 in astrocytes via $\mathrm{H}_{2} \mathrm{O}_{2}$, semiquinones, and quinones. Free Radic Biol Med 2011;51:2319-27.

68. Zieger MA, Glofcheski DJ, Lepock JR, Kruuv J. Factors influencing survival of mammalian cells exposed to hypothermia. V. Effects of hepes, free radicals, and $\mathrm{H}_{2} \mathrm{O}_{2}$ under light and dark conditions. Cryobiology 1991;28:8-17.

69. Wang RJ, Nixon BR. Identification of hydrogen peroxide as a photoproduct toxic to human cells in tissue-culture medium irradiated with "daylight" fluorescent light. In Vitro 1978;14:715-22.

70. Sandstrom PA, Buttke TM. Autocrine production of extracellular catalase prevents apoptosis of the human CEM T-cell line in serum-free medium. Proc Natl Acad Sci USA 1993;90:4708-12.

71. Isuzugama K, Inoue M, Ogihara Y. Catalase contents in cells determine sensitivity to the apoptosis inducer gallic acid. Biol Pharm Bull 2001;24:1022-6.

72. Wee LM, Long LH, Whiteman M, Halliwell B. Factors affecting the ascorbate- and phenolic-dependent generation of hydrogen peroxide in Dulbecco's modified Eagles medium. Free Radic Res 2003;37:1123-30.

73. Yamada H, Adachi T, Fukatsu A, Misao S, Yamada Y, Aoki T, et al. Extracellular superoxide dismutase and glomerular mesangial cells: Its production and regulation. FEBS Lett 2002;519:77-81.

74. Kemp K, Hares K, Mallam E, Heesom KJ, Scolding N, Wilkins A. Mesenchymal stem cell-secreted superoxide dismutase promotes cerebellar neuronal survival. J Neurochem 2010;114:1569-80.
75. Long LH, Hoi A, Halliwell B. Instability of, and generation of hydrogen peroxide by, phenolic compounds in cell culture media. Arch Biochem Biophys 2010;501:162-9.

76. Linnewiel K, Ernst H, Caris-Veyrat C, Ben-Dor A, Kampf A, Salman H. Structure activity relationship of carotenoid derivatives in activation of the electrophile/antioxidant response element transcription system. Free Radic Biol Med 2009;47:659-67.

77. Clement MV, Long LH, Ramalingam J, Halliwell B. The cytotoxicity of dopamine may be an artefact of cell culture. J Neurochem 2002;81:414-21.

78. Schaffer S, Halliwell B. Comment on hydroxytyrosol induces proliferation and cytoprotection against oxidative injury in vascular endothelial cells: Role of Nrf2 activation and HO-1 induction. J Agric Food Chem 2011;59:10770-1.

79. Tang SY, Halliwell B. Medicinal plants and antioxidants: What do we learn from cell culture and Caenorhabditis elegans studies? Biochem Biophys Res Commun 2010;394:1-5.

80. Wachtel-Galor S, Choi SW, Benzie IF. Effect of Ganoderma lucidum on human DNA is dose dependent and mediated by hydrogen peroxide. Redox Rep 2005;10:145-9.

81. Hong J, Kwon SJ, Sang S, Ju J, Zhou JN, Ho CT, et al. Effects of garcinol and its derivatives on intestinal cell growth: Inhibitory effects and autoxidation-dependent growth-stimulatory effects. Free Radic Biol Med 2007;42:1211-21.

82. Grzelak A, Rychlik B, Bartosz G. Reactive oxygen species are formed in cell culture media. Acta Biochim Pol 2000;47:1197-8.

83. Long LH, Halliwell B. Coffee drinking increases levels of urinary hydrogen peroxide detected in healthy human volunteers. Free Radic Res 2000;32:463-7. 